\title{
Management of a shallow temperate estuary to control eutrophication: The effect of hydrodynamics on the system's nutrient loading
}

\author{
A.I. Lillebø*, J.M. Neto, I. Martins, T. Verdelhos, S. Leston, P.G. Cardoso, \\ S.M. Ferreira, J.C. Marques, M.A. Pardal \\ IMAR - Institute of Marine Research, Department of Zoology, University of Coimbra, 3004-517 Coimbra, Portugal
}

Received 13 January 2005; accepted 15 July 2005

Available online 26 August 2005

\begin{abstract}
The Mondego estuary, a shallow warm-temperate intertidal system located on the west coast of Portugal, has for some decades been under severe ecological stress, mainly caused by eutrophication. Water circulation in this system was, until 1998, mainly dependent on tides and on the freshwater input of a small tributary artificially controlled by a sluice. After 1998, the sluice opening was effectively minimised to reduce the nutrient loading, and the system hydrodynamics improved due to engineering work in the upstream areas. The objective of the present study was to evaluate the effect of the mitigation measures implemented in 1998. Changes to the hydrodynamics of the system were assessed using precipitation and salinity data in relation to the concentrations of dissolved inorganic nutrients, as well as the linkage between dissolved N:P ratios and the biological parameters (phytoplankton chlorophyll $a$ concentrations, green macroalgal biomass and seagrass biomass). Two distinctive periods were compared, over a ten year period: from January 1993 to January 1997 and from January 1999 until January 2003. The effective reduction in the dissolved $\mathrm{N}: \mathrm{P}$ atomic ratio from 37.7 to 13.2 after 1998 is a result of lowered ammonia, but not the oxidised forms of nitrogen (nitrate plus nitrite), or increased concentrations of dissolved inorganic phosphorus. Results suggest that the phytoplankton is not nutrient limited, yet maximum and mean biomass of green macroalgae was reduced by one order of magnitude after the mitigation measures. This suggests that besides lowering the water residence time of the system, macroalgal growth became nitrogen limited. In parallel to these changes the seagrass-covered area and biomass of Zostera noltii showed signs of recovery.
\end{abstract}

(C) 2005 Elsevier Ltd. All rights reserved.

Keywords: hydrodynamics; river management; phosphorus; nitrogen; chlorophyll a; Ulva, Zostera, Hysteresis

\section{Introduction}

Worldwide, the nutrient enrichment of shallow coastal areas has led to a decline in environmental quality, especially close to densely populated areas affected by eutrophication. As a result of nutrientinduced changes, particularly increased levels of growth

\footnotetext{
* Corresponding author.

E-mail address: lillebo@ci.uc.pt (A.I. Lillebø).
}

limiting nutrients, perennial benthic macrophytes are commonly replaced by fast-growing opportunistic algae (epiphytic green macroalgae and/or phytoplankton), which in many systems has affected the entire trophic structure (e.g. Valiela et al., 1997; Raffaelli et al., 1998; Cardoso et al., 2004). Thus, conservation and restoration of coastal areas has become a priority during the last decades (de Jonge, 2000; van Katwijk et al., 2000; de Jonge and de Jong, 2002; Kendrick et al., 2002). The general aim of restoration programmes is to return a system from an altered or disturbed condition to 
a previously existing stable state condition (Zhang et al., 2003; Webster and Harris, 2004). Yet, when the response trajectory of the system to reduced driving variable (e.g. nutrient loads reduction) is very different from the trajectory as the driving variable intensifies (e.g. rising nutrient loads), the system shows pronounced hysteresis (Scheffer et al., 2001; Beisner et al., 2003; Webster and Harris, 2004). Eutrophication may push the system into an alternate stable state by positive feedback processes from which recovery is very difficult to achieve (Scheffer et al., 2001). Thus, to assess the success of restoration programmes it is necessary to understand the processes which have driven the observed ecological changes and to monitor the restoration process (Zhang et al., 2003; Cardoso et al., 2004, Pardal et al., 2004; Webster and Harris, 2004).

The main inputs contributing to the nutrient balance and status of estuarine systems are the external point and diffuse sources plus the internal biogeochemical mineralization processes (Zwolsman, 1994; Lillebø et al., 2004; Coelho et al., 2004). Additionally, the physical and chemical characteristics and the ecology of these shallow, yet highly complex and dynamic ecosystems are strongly influenced by the hydrology of the systems (Martins et al., 2001).

Like many other estuaries worldwide (McMahon and Walker, 1998; Beukema et al., 1999; Norkko and Bonsdorff, 2000; Sfriso et al., 2001), the Mondego estuary has been under environmental stress by eutrophication processes. As a consequence, the seagrass (Zostera noltii) bed has almost disappeared, reducing in extent from 15 ha in the early 1980's to 0.02 ha in the mid-1990's (e.g. Dolbeth et al., 2003; Marques et al., 2003; Pardal et al., 2004). To evaluate the effect of the implemented mitigation measures, in 1998, the objective of the present study was to assess the hydrodynamics, using precipitation and salinity data, in relation to the concentrations of dissolved inorganic nutrients, as well as the linkage between dissolved N:P ratios with the biological parameters (phytoplankton chlorophyll $a$ concentrations, green macroalgal biomass and seagrass biomass) before and after 1998, over a 10-year period.

\section{Material and methods}

\subsection{Description of the study site}

The Mondego estuary is a warm-temperate intertidal system located on the west coast of Portugal (Fig. 1). The construction of harbour facilities has imposed severe changes of this system since the 1930s, particularly the construction of stone walls to regulate the main navigation channels, and the construction of small water reservoirs for agriculture and aquaculture purposes. The
Mondego estuary is relatively small (1600 ha) and receives agricultural runoff from 15000 ha of upstream cultivated land, mainly dominated by rice fields. The main changes that have affected the system include modified riverbed topography, changed hydrodynamics, increased water turbidity and increased concentration of growth limiting nutrients (Martins et al., 2001).

The Mondego estuary is about $7 \mathrm{~km}$ long and is 2$3 \mathrm{~km}$ across at its widest part, and comprises a northern and southern arm, separated by the Murraceira island. The northern arm is the deeper $( \pm 10 \mathrm{~m}$ during high tide, tidal range $0.5-3.5 \mathrm{~m}$ ), constituting the main navigation channel and the location of the Figueira da Foz harbour. The southern arm is shallower (2-4 m during high tide), and is characterised by large areas of intertidal flats exposed during low tide. Until 1998, the southern arm was almost silted up in the innermost areas, and the river outflow occurred mainly via the northern arm (Fig. 1). Water circulation in the southern arm was mostly dependent on the tides and on the freshwater input from the Pranto River, a small tributary with a flow controlled by a sluice, which was regulated according to the water level of rice fields in the Mondego Valley (Fig. 1). This freshwater input represented an important source of nutrients into the southern arm. Thus, the system has been under environmental stress by eutrophication processes. A previous study, conducted between January 1993 and January 1997, concluded that the inter-annual variation of macroalgal biomass in the Mondego estuary was controlled by hydrodynamics, which in turn depended on precipitation and river management, according to the water requirements of the upstream rice crop (Martins et al., 2001).

The Pranto river sluice opening was effectively reduced in 1998 to lower the nutrient loading of the south arm. Most of the nutrient enriched Pranto freshwater is diverted to the northern arm by another sluice located further upstream. Furthermore, to improve the hydraulic regime, the upstream connection between the two arms was enlarged, allowing water to flow from the north arm at high tide situations (Fig. 1). In addition, the remaining seagrass patches were protected with wooden stakes to prevent further disturbance of that area (by fishermen who were digging in the sediment looking for bait), and several forums were convened to apprise local people of the ecological and economic importance of the seagrass bed.

\subsection{Sampling procedure and analysis}

The long-term monitoring program in the Mondego estuary has been carried out since the early 1990s by an IMAR-Institute research team, within the scope of European and national projects. In order to assess the eutrophication process in the south arm of the estuary, three distinct areas were monitored (A, B and $\mathrm{C}$ in 


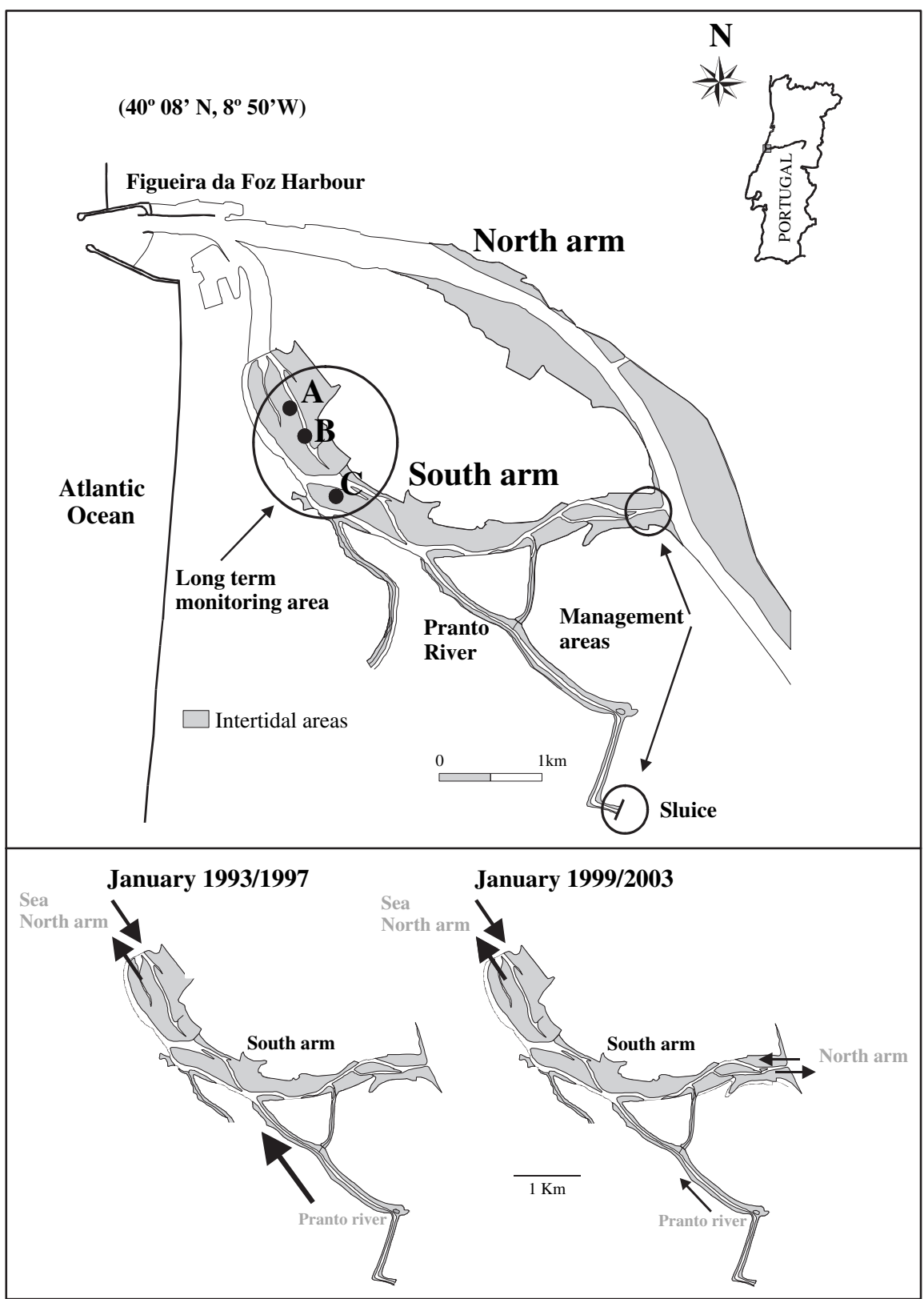

Fig. 1. The Mondego estuary, with the location of the long term monitoring area (A, B and C, where the macroalgal coverage gradient increases from downstream to upstream); the alterations implemented in 1998 and the freshwater main point sources before and after the management.

Fig. 1). The choice of these areas was dictated by observations of a macroalgal coverage gradient in the south arm, increasing from downstream to upstream. Originally, in the early 1980's, the three areas were covered by rooted macrophytes; however, as the eutrophication increased, together with human disturbance caused by an intensive baitdigging, Zostera noltii declined progressively. Currently, the seagrass bed is restricted to the marine end of the estuary, having been replaced elsewhere by green macroalgae.

At each sampling site, primary producers and associated macrofauna were sampled monthly (minimum 6 cores, with $141 \mathrm{~cm}^{2}$ section) between January
1993 and January 2003. Sampling was conducted during the day period just after ebbing. At the same time, water temperature and salinity were measured, while water samples (approximately $250 \mathrm{ml}$ ) were collected for analysis of dissolved inorganic nitrogen and phosphorus. Samples were immediately filtered (Whatman $\mathrm{GF} / \mathrm{F}$ glass-fibre filter) and stored frozen at $-18{ }^{\circ} \mathrm{C}$ until analysis following standard methods described in Limnologisk Metodik (1992) for ammonia $\left(\mathrm{NH}_{3}-\mathrm{N}\right)$ and phosphate $\left(\mathrm{PO}_{4}-\mathrm{P}\right)$ and in Strickland and Parsons (1972) for nitrate $\left(\mathrm{NO}_{3}-\mathrm{N}\right)$, and nitrite $\left(\mathrm{NO}_{2}-\mathrm{N}\right)$. It is possible that underestimation of ammonia occurred due to temporary freezing of samples. The phytoplankton 
chlorophyll $a(\mathrm{Chl} a)$ determinations were performed by filtering $0.5-1.0 \mathrm{~L}$ of water through Whatman $\mathrm{GF} / \mathrm{C}$ glass-fibre filters followed by extraction according to Parsons et al. (1985). In the field and during transportation to the lab, samples were stored on ice and light protected. Samples from the three monitoring areas (A, B and C) were collected and analysed separately. Due to the small distance between the sites, data were put together and presented/related as mean values $( \pm \mathrm{SE})$ for the south arm of the estuary. Green macroalgae (mostly Ulva intestinalis and Ulva compressa, according to the recent revision of Hayden et al., 2003) and the seagrass Zostera noltii, were dried (for $48 \mathrm{~h}$ at $60{ }^{\circ} \mathrm{C}$ ) and ash free dry weight (AFDW) was assessed after combustion of samples for $8 \mathrm{~h}$ at $450{ }^{\circ} \mathrm{C}$.

\section{Results}

The seasonal and inter-annual variation of salinity in the south arm of the Mondego estuary is strongly influenced by precipitation (Fig. 2). These two parameters showed a highly significant $(P<0.001)$ negative linear relationship for both periods of study, although with higher correlation for the 1999-2003 period.

The changes implemented in the hydrodynamics of the system promoted a noteworthy reduction in the concentration of the ammonia, but not in the oxidised forms of nitrogen (nitrate plus nitrite) or in the concentrations of the dissolved inorganic phosphorus (Fig. 3). The concentrations of ammonia ranged between $7.6 \mu \mathrm{mol} \mathrm{L}^{-1}$ and $84.3 \mu \mathrm{mol} \mathrm{L}^{-1}$ during the 1993-1997 period, and after the Pranto river sluice aperture was effectively reduced, the ammonia concentrations dropped to values lower than $15 \mu \mathrm{mol} \mathrm{L}{ }^{-1}$, (Table 1). The concentrations of oxidised nitrogen forms were not significantly different with a mean value of $7.2 \mu \mathrm{mol} \mathrm{N} \mathrm{L}{ }^{-1}$ in the first period, and $7.4 \mu \mathrm{mol} \mathrm{N} \mathrm{L}{ }^{-1}$ after 1998 (Table 1). Similarly, there were no significant differences between phosphate concentrations before and after 1998 (Table 1). For both periods, before and after 1998, the oxidised forms of nitrogen exhibited
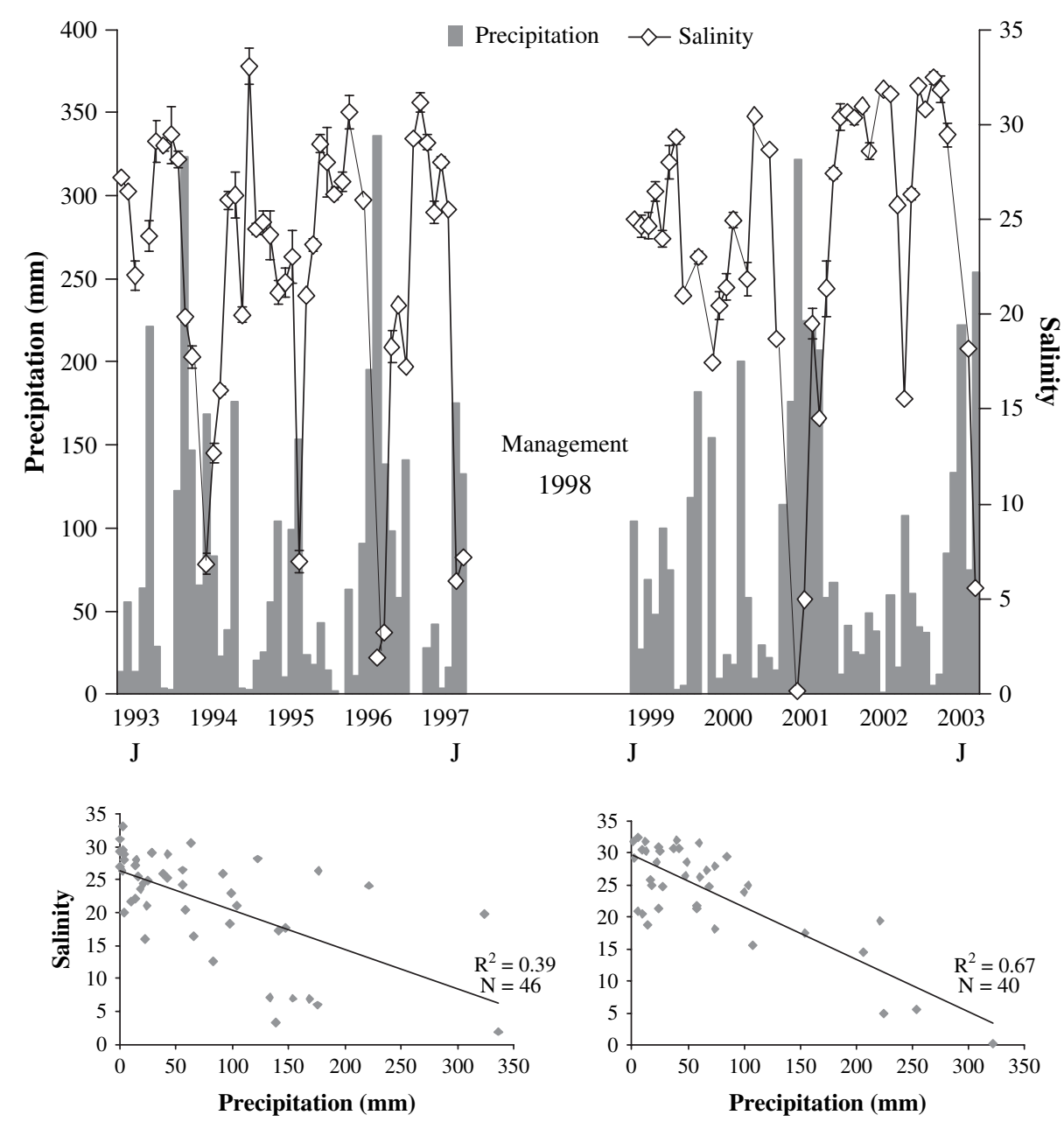

Fig. 2. The variation of precipitation $(\mathrm{mm})$ and salinity (mean $\pm \mathrm{SE}$ ) between January 1993 and January 2003, and the relation between precipitation $(\mathrm{mm})$ and salinity before (1993-1997) and after (1999-2003) the management. 


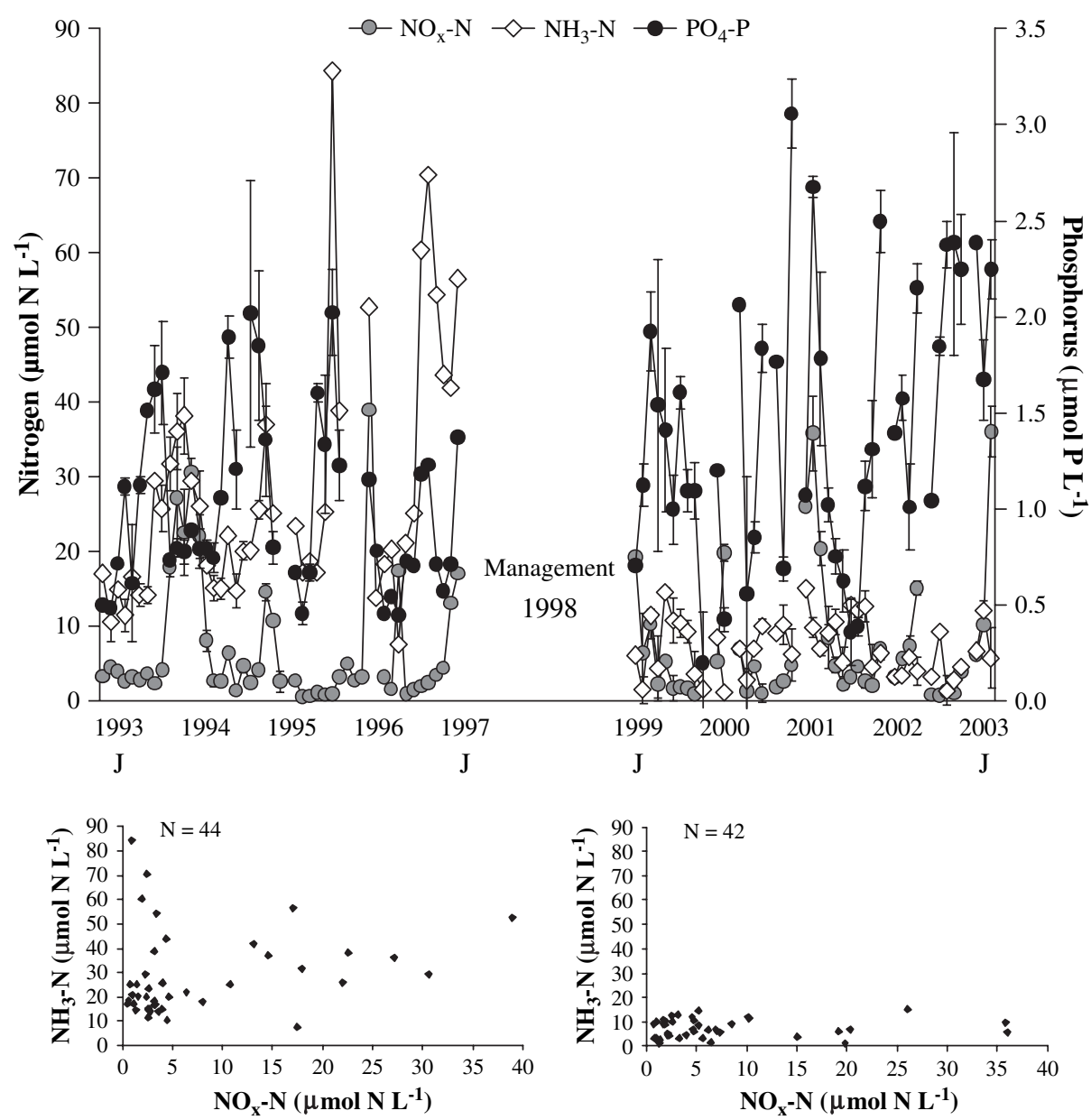

Fig. 3. Comparison of the dissolved inorganic nutrients concentrations (nitrate + nitrite, ammonia and phosphate, mean \pm SE) before (1993-1997) and after (1999-2003) the management.

Table 1

The concentration of nutrients and the biomass of primary producers during the pre-mitigation period, 1993-1997 (A) and post-mitigation period, 1999-2003 (B), and the statistical significance of differences concerning these parameters between the two periods (C)

\begin{tabular}{|c|c|c|c|c|c|c|c|c|c|c|c|c|}
\hline & \multirow{2}{*}{$\begin{array}{l}\text { A } \\
\left(\mu \mathrm{mol} \mathrm{L}{ }^{-1}\right)\end{array}$} & \multicolumn{4}{|c|}{ January 1993/1997 } & \multirow{2}{*}{$\begin{array}{l}\text { B } \\
\left(\mu \mathrm{mol} \mathrm{L} \mathrm{L}^{-1}\right)\end{array}$} & \multicolumn{4}{|c|}{ January $1999 / 2003$} & \multirow[t]{2}{*}{$\mathrm{C}$} & \multirow{2}{*}{$\begin{array}{l}\text { Wilcoxon two } \\
\text { sample test }\end{array}$} \\
\hline & & Max. & Min. & Mean & $\pm \mathrm{SE}$ & & Max. & Min. & Mean & $\pm \mathrm{SE}$ & & \\
\hline \multirow[t]{3}{*}{ Nutrients } & $\mathrm{NH}_{3}-\mathrm{N}$ & 84.3 & 7.6 & 28.9 & 2.6 & $\mathrm{NH}_{3}-\mathrm{N}$ & 15.0 & 1.2 & 7.2 & 0.6 & $\mathrm{NH}_{3}-\mathrm{N}$ & \multirow{3}{*}{$\begin{array}{l}\text { (Significant: } \\
W=946.0 ; \\
P<0.001 \text { ) } \\
\text { (n.s.: } W=1626.0 ; \\
P>0.05 \text { ) } \\
\text { (n.s.: } W=1549.5 ; \\
P>0.05 \text { ) }\end{array}$} \\
\hline & $\mathrm{NO}_{\mathrm{x}}-\mathrm{N}$ & 0.50 & 38.9 & 7.2 & 1.3 & $\mathrm{NO}_{\mathrm{x}}-\mathrm{N}$ & 0.74 & 36.1 & 7.4 & 1.4 & $\mathrm{NO}_{\mathrm{x}}-\mathrm{N}$ & \\
\hline & $\mathrm{PO}_{4}-\mathrm{P}$ & 2.02 & 0.44 & 1.01 & 0.07 & $\mathrm{PO}_{4}-\mathrm{P}$ & 3.06 & 0.20 & 1.43 & 0.11 & $\mathrm{PO}_{4}-\mathrm{P}$ & \\
\hline \multirow[t]{3}{*}{$\begin{array}{l}\text { Primary } \\
\text { producers }\end{array}$} & $\begin{array}{l}\text { Phytoplankton } \\
\text { (mg Chl. } a \mathrm{~m}^{-3} \text { ) }\end{array}$ & 14.7 & 1.7 & 6.1 & 0.57 & $\begin{array}{l}\text { Phytoplankton } \\
\text { (mg Chl. } a \mathrm{~m}^{-3} \text { ) }\end{array}$ & 12.9 & 1.4 & 5.9 & 0.43 & $\begin{array}{l}\text { Phytoplankton } \\
\text { (mg Chl. } a \mathrm{~m}^{-3} \text { ) }\end{array}$ & \multirow{3}{*}{$\begin{array}{l}\text { (n.s.: } W=749.0 \\
P>0.05) \\
\text { (Significant: } \\
W=2059.0 \\
P<0.001 \text { ) } \\
\text { (Significant: } \\
W=2352.0 \\
P<0.001 \text { ) }\end{array}$} \\
\hline & $\begin{array}{l}\text { Green algae } \\
\left(\text { g AFDW m }^{-2}\right)\end{array}$ & 127.0 & 0.0 & 21.5 & 5.22 & $\begin{array}{l}\text { Green algae } \\
\left(\mathrm{g} \mathrm{AFDW} \mathrm{m}^{-2}\right)\end{array}$ & 13.6 & 0.0 & 2.2 & 0.51 & $\begin{array}{l}\text { Green algae } \\
\left(\mathrm{g} \mathrm{AFDW} \mathrm{m}^{-2}\right)\end{array}$ & \\
\hline & $\begin{array}{l}\text { Seagrasses } \\
\left(\mathrm{g}_{\text {AFDW m }}{ }^{-2}\right)\end{array}$ & 256.6 & 5.7 & 140.8 & 11.5 & $\begin{array}{l}\text { Seagrasses } \\
\left(\mathrm{g} \mathrm{AFDW} \mathrm{m}^{-2} \text { ) }\right.\end{array}$ & 158.9 & 18.3 & 76.3 & 4.9 & $\begin{array}{l}\text { Seagrasses } \\
\left(\mathrm{g}_{\text {AFDW m }}^{-2} \text { ) }\right.\end{array}$ & \\
\hline
\end{tabular}


a highly significant $(P<0.001)$ negative linear relation with salinity (1993-97 $R^{2}=0.67, N=46$ and $1999-03$ $\left.R^{2}=0.67, N=42\right)$ and a highly significant $(P<0.001)$ positive linear relationship with precipitation (1993-97 $R^{2}=0.40, N=47$ and $\left.1999-03 R^{2}=0.43, N=41\right)$ (Fig. 4), suggesting that the Mondego system main source for these nutrients are the freshwater inputs.

The mean water temperature showed a clear seasonal variation, closely following the air temperature (Fig. 5). Phosphate concentrations showed a highly significant $(P<0.001)$ positive linear relationship with water temperature $\left(R^{2}=0.44, N=40\right)$ for the 1993-1997 period, suggesting a clear dependency on mineralization processes. After 1998, this relationship disappeared and high concentrations of phosphate were present even at low temperatures.

Ammonia did not show any relationship with precipitation, salinity, temperature, nor with the other dissolved inorganic nutrients $\left(\mathrm{NO}_{\mathrm{x}}-\mathrm{N}\right.$ and $\left.\mathrm{PO}_{4}-\mathrm{P}\right)$. The dissolved N:P atomic ratio showed a significant decrease (Wilcoxon two sample test: $W=2882.5 ; P<0.001$ ) from the pre- (mean N:P $=37.7$ ) to post-management (mean $\mathrm{N}: \mathrm{P}=13.2$ ) period (Fig. 6), mostly due to the reduction in the concentration of ammonia. This
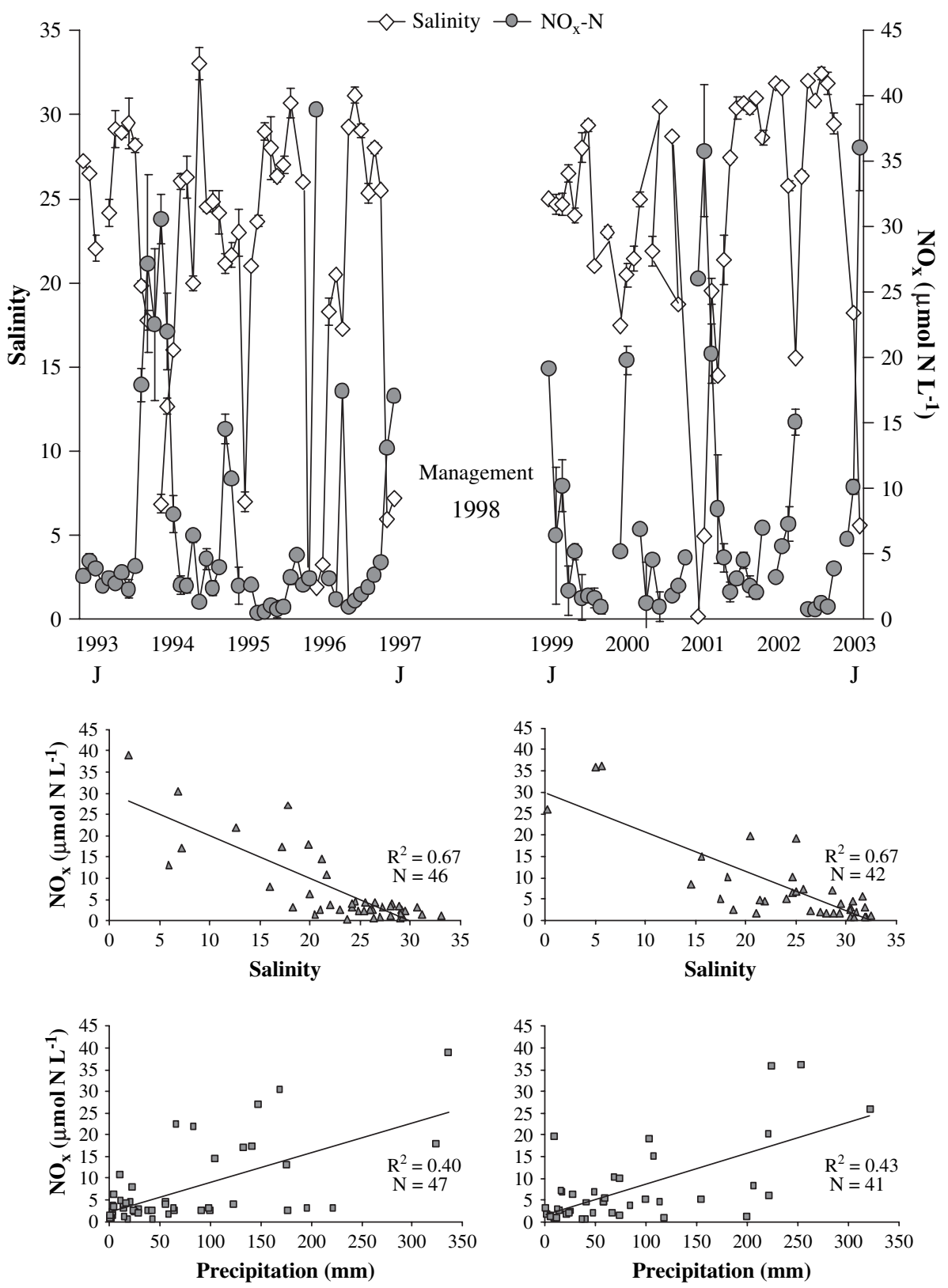

Fig. 4. The variation of salinity (mean $\pm \mathrm{SE}$ ) and the concentration of the oxidised forms of nitrogen $\left(\mathrm{NO}_{\mathrm{x}}=\mathrm{NO}_{3}-\mathrm{N}+\mathrm{NO}_{2}-\mathrm{N}, \mathrm{mean} \pm \mathrm{SE}\right)$ between January 1993 and January 2003, and the relation between salinity and the oxidised forms of nitrogen, and precipitation and the oxidised forms of nitrogen before (1993-1997) and after (1999-2003) the management. 


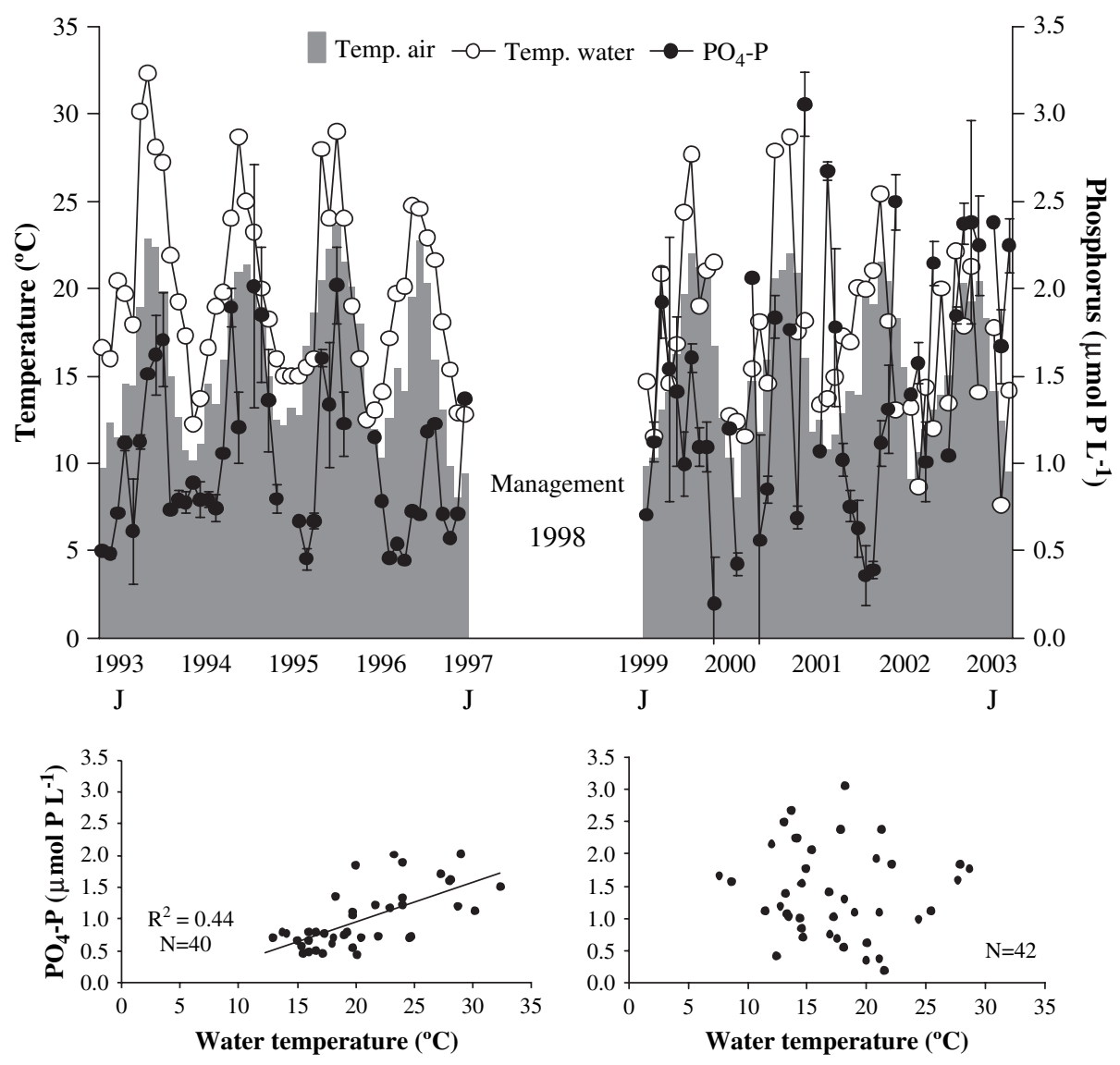

Fig. 5. The variation of mean temperature $\left({ }^{\circ} \mathrm{C}\right)$ in the air and in the water, and the concentration of phosphate $(\mathrm{PO}$ - $\mathrm{P}$, mean $\pm \mathrm{SE})$ between $\mathrm{January}$ 1993 and January 2003, and the relation between mean water temperature and the concentration of phosphate before (1993-1997) and after (19992003) the management.

difference is evidenced by analysing the dissolved $\mathrm{N}: \mathrm{P}$ atomic ratio, separating the nitrogen oxidize forms (NOx-N:P) from ammonia $\left(\mathrm{NH}_{3}-\mathrm{N}: \mathrm{P}\right)$ (Fig. 6). For both periods, the dissolved $\mathrm{N}: \mathrm{P}$ atomic ratio exhibited a highly significant $(P<0.001)$ negative linear relation with salinity (1993-97 $R^{2}=0.55, N=35$ and 1999-03 $R^{2}=0.67, N=40$ ) (Fig. 6).

The biological parameters for opportunistic primary producers showed that green macroalgal biomass, mostly Ulva intestinalis and Ulva compressa, was significantly reduced (Table 1) after the implementation of the mitigation measures (Fig. 7A): maximum biomass 127.0 $\mathrm{g} \mathrm{AFDW} \mathrm{m}^{-2}$ before and $13.6 \mathrm{~g} \mathrm{AFDW} \mathrm{m}^{-2}$ after 1998. Yet, the phytoplankton chlorophyll $a$ concentrations did not differ (Fig. 7): mean concentration: $6.1 \mathrm{mg} \mathrm{m}^{-3} \pm 0.6 \mathrm{SE}$ before and $5.9 \mathrm{mg} \mathrm{m}^{-3} \pm 0.4 \mathrm{SE}$ after 1998 (Table 1).

The biomass of Zostera noltii sharply decreased from January 1993 to January 1997, (Fig. 7B). After the mitigation measures, the seagrass partly recovered: maximum and minimum biomass was respectively 256.6 and $5.7 \mathrm{~g}$ AFDW $\mathrm{m}^{-2}$ before and 158.9 and $18.3 \mathrm{~g} \mathrm{AFDW} \mathrm{m}^{-2}$ after 1988 . However, the biomass was still significantly lesser than in the first period (Table 1).

\section{Discussion}

Water circulation in the south arm of the Mondego estuary was mainly dependent on tides and freshwater input by the tributary Pranto river during the period of 1993 to 1997 . This is clear from the highly significant negative linear relation between salinity and precipitation. Comparatively, in the post-management period, the explained variance was lower, which is supported by a time lag between the occurrence of precipitation and the freshwater discharge from the River sluice (Martins et al., 2001). After the enlargement of the upstream connection between the two arms, higher variance in the negative linear relation between salinity and precipitation clearly suggests a higher freshwater input from the north arm through overflow episodes. Despite the changes in the hydrodynamics of the system, the highest salinities were recorded during the warmer/dry periods, when the freshwater inputs are lower and the runoff episodes negligible. This indicates a major penetration of seawater during spring and summer. On the other hand, during autumn and winter the considerable increase and predominance of freshwater inputs lower the salinity. 

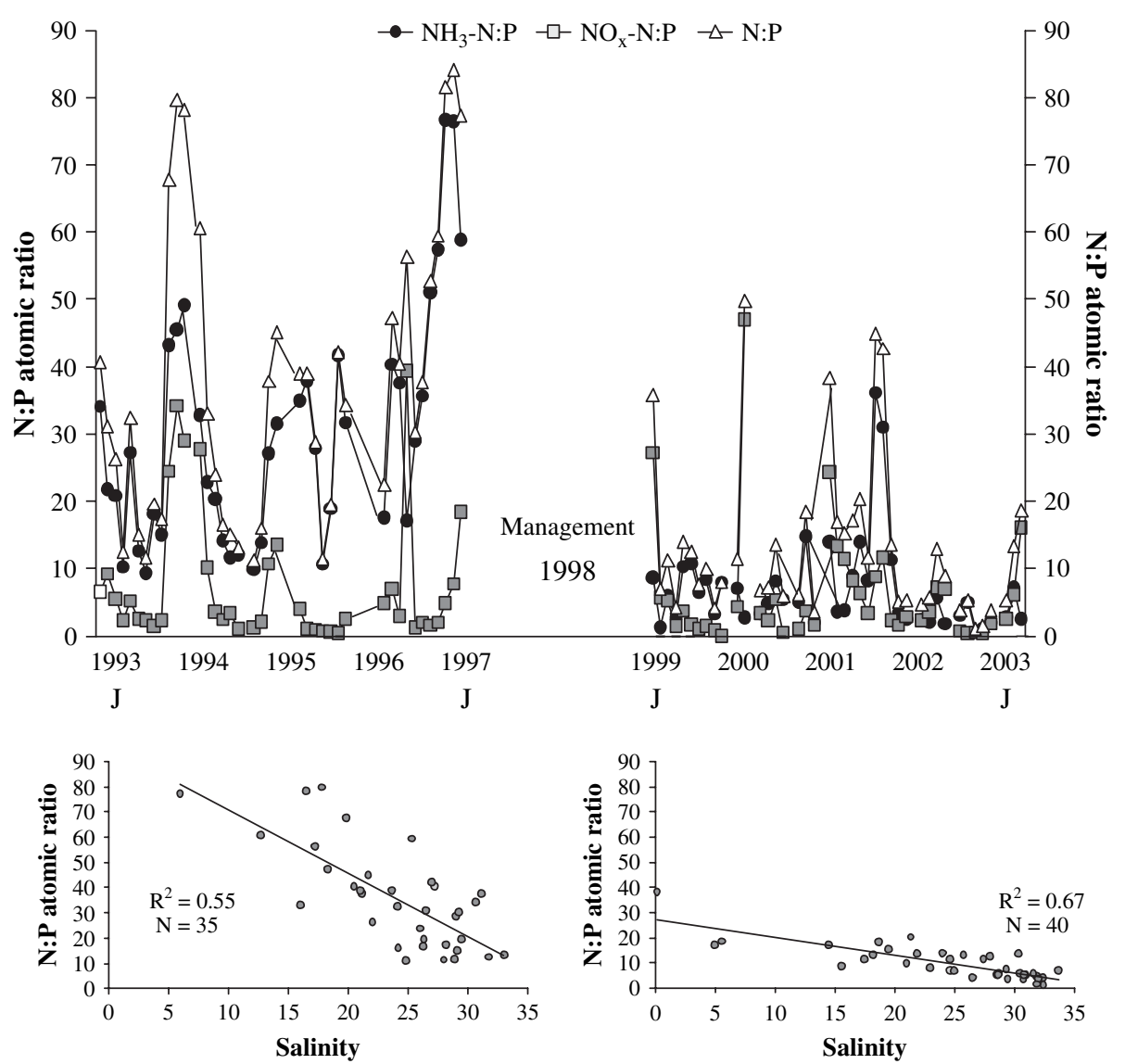

Fig. 6. Comparison of the N:P atomic ratio in the water, between January 1993 and January 2003, considering the total dissolved inorganic nitrogen, just the ammonia form of nitrogen and just the oxidised forms of nitrogen, and the relation between the N:P atomic ratio and salinity before (1993-1997) and after (1999-2003) the management.

For both periods, before and after 1998, there is a highly significant negative linear relation between salinity and the oxidised forms of dissolved nitrogen and a highly significant positive linear relation between precipitation and the oxidised forms of dissolved nitrogen, suggesting a strong dependency on the freshwater inputs from diffuse and/or point sources The oxidized nitrogen forms were not significantly reduced after 1998. Probably due to the fact that concentrations of nitrogen are often several times higher in rivers than in receiving coastal seawater (Yin et al., 2001), and this estuarine system receives an agricultural runoff from an upstream cultivated area ten times larger than the estuary itself. Moreover, rain water can also constitute a source of nitrate to aquatic systems (Berner and Berner, 1996).

Rivers may supply much of the nitrogen and phosphorus to estuaries, but most of it may also internally recycle within the estuary through biogeochemical processes. Thus, external sources for nutrients can also include the regeneration of nutrients from organic and inorganic matter carried by rivers (Berner and Berner, 1996). So, the Pranto river could also constitute a source of nutrients in the form of suspended particulate organic and/or inorganic matter.
The absence of a linear relationship between ammonia and salinity or precipitation, and between phosphate and salinity or precipitation, before and after 1998, suggests that the main source of these nutrients, in the dissolved form, was not dependent on the freshwater inputs. Both nutrients can be directly related to the biological activity and mineralization of organic matter within the system (e.g. Berner and Berner, 1996; Lillebø et al., 2002). In fact, most of the phosphorus enters the system in the particulate form (Lillebø et al., 2002). For the period 1993 to 1997 , the highly significant positive linear relation of phosphate with temperature implies a dependency on mineralization processes (Asmus et al., 2000; Lillebø et al., 2002, 2004). This means that ecological stress may still persist due to internal Ploading (Coelho et al., 2004) in a similar way as observed in other temperate estuaries (Holmboe et al., 1999) and shallow lakes (e.g. Jensen and Andersen, 1992; Zhang et al., 2003). After 1998, this relation is not significant, since high phosphate concentrations also persist into autumn and winter, with low temperatures (between $6{ }^{\circ} \mathrm{C}$ and $12{ }^{\circ} \mathrm{C}$ ), suggesting the existence of additional phosphate sources, possibly aquaculture farms or small industries. 
A
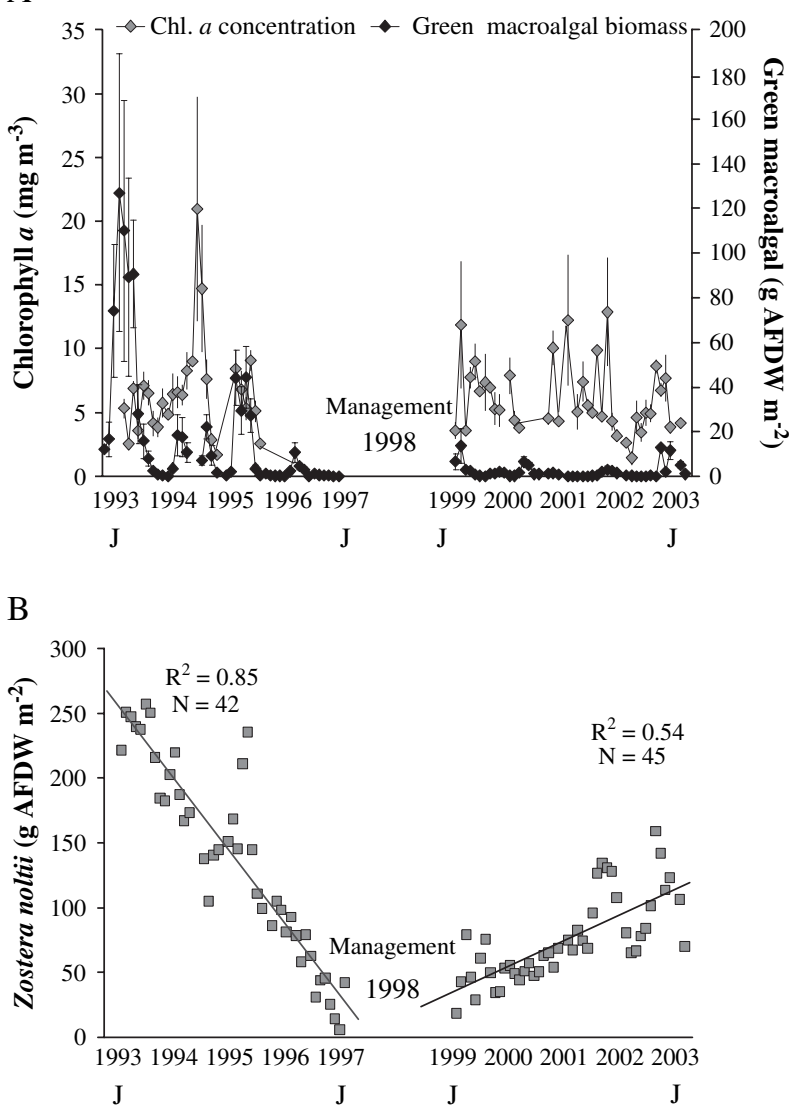

$\mathrm{C}$

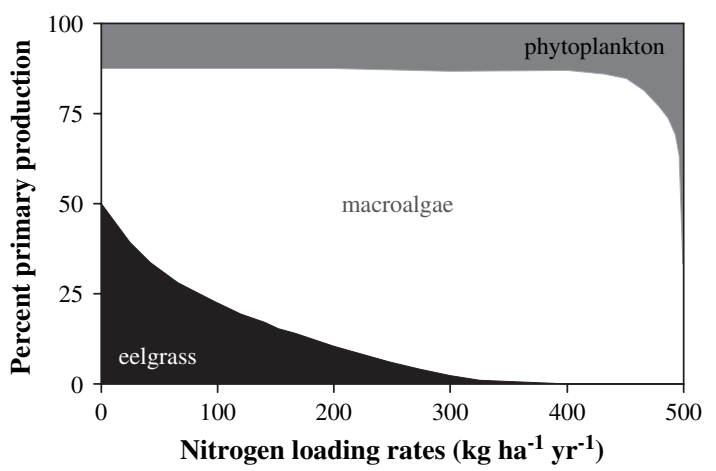

Fig. 7. A) Comparison of the mean concentration of chlorophyll $a$ ( $\mathrm{mg} \mathrm{m}^{-3}$, mean $\pm \mathrm{SE}$ ) and the mean biomass of green macroalgae (mg AFDW m ${ }^{-2}$, mean \pm SE) before the management (1993-1997) and after (1999-2003); B) Comparison of the mean biomass of Zostera noltii at the long monitoring field station A $\left(\mathrm{mg} \mathrm{AFDW} \mathrm{m}^{-2}\right)$ before the management (1993-1997) and after (1999-2003); C) Hypothetical pattern of change in the relative contribution of these three major groups of producers in shallow temperate estuaries with shorter water residence time, redrawn after Valiela et al. (1997).

Ammonia did not show any relationship with temperature, which is in agreement with previous studies showing that primary producers may control the sediment/water flux of ammonia (Lillebø et al., 2002). Higher ammonia efflux rates occur seasonally, when primary producers are less active (autumn and winter), and daily when heterotrophic respiration is not compensated by primary production (night period) (Lillebø et al., 2002).

After the diversion of most of the freshwater from the Pranto river directly into the northern arm, through another sluice located further upstream, the concentrations of ammonia in the south arm were effectively reduced. This suggests that the river Pranto was previously the major source for the ammonia form of nitrogen. In addition, a linear correlation often exists between ammonia concentrations and the suspended particulate matter in the water column of temperate intertidal shallow systems (Rocha et al., 1995).

For both periods (pre- and post-mitigation), the dissolved N:P atomic ratio exhibited a highly significant negative linear relation with salinity, suggesting a close relation with the freshwater inputs. Since no relevant changes occurred in the concentrations of dissolved inorganic phosphorus between pre- and post-mitigation, lack of ammonia derived from the Pranto river caused the effective reduction in the $\mathrm{N}: \mathrm{P}$ atomic ratio after the regulation. The opportunistic primary producer parameters suggest that phytoplankton is not nutrient limited, since chlorophyll $a$ concentrations did not show any significant changes throughout the period between 1993 and 2003. Due to a comparatively higher surface area/ volume relation, phytoplankton have higher affinity for nitrogen forms, with higher uptake rates than macroalgae for both ammonia and nitrate per unit of biomass (Hein et al., 1995; Collos, 1998). However, this only makes phytoplankton competitively superior under low nitrogen availability, which is closely related to nitrogen loading and water residence time (Hein et al., 1995; Valiela et al., 1997). On the other hand, the biomass of green macroalgae was reduced about one order of magnitude after the mitigation measures. This shows that the improvement of the hydrodynamics of the system lowered dissolved inorganic nitrogen concentrations, which caused macroalgae with low nitrogen affinity to be nitrogen limited. In fact, nitrogen often appears to be the limiting nutrient in estuarine systems (Hein et al., 1995; Yin et al., 2001), namely in the form of ammonia (Rocha et al., 1995). Ultimately, the response of phytoplankton, green macroalgae and the seagrass Zostera noltii to the changes of nitrogen loading in the Mondego estuary clearly confirms the pattern of relative contribution of these three major groups of producers, in shallow temperate estuaries with shorter water residence time, proposed by Valiela et al. (1997) (Fig. 7C).

Aquatic ecosystems may shift between an oligotrophic/benthic state (with clear water and macrophyte dominated) and an euthrophic/pelagic state (with turbid water and plankton dominated) (Valiela et al., 1997; Scheffer et al., 2001; Zhang et al., 2003; Webster and Harris, 2004). The switch between the two states is often 
abrupt and the ecosystem response to perturbation is highly non-linear and complex (Scheffer et al., 2001; Beisner et al., 2003; Marques et al., 2003; Zhang et al., 2003; Cardoso et al., 2004). The non-linearity arises from the strong interactions between the benthos and the pelagic compartments and from competition between primary producers for light and nutrients (Scheffer et al., 2001; Zhang et al., 2003; Webster and Harris, 2004). When the mean dissolved N:P ratio was reduced in the Mondego system, the large green macroalgae biomass was reduced, followed by an increase of Zostera noltii biomass and covered area. Yet, seagrass biomass and aerial cover remained much lower than during the initial state. These primary producers are bio-stabilisers due to the immediate changes in the physical environment (e.g. decreasing tidal currents, wave action and sediment resuspension and enhancing sediment cohesiveness and settling of suspended matter (Widdows and Brinsley, 2002). The hysteresis response may be related to the sedimentary changes that followed the loss of seagrass (Cardoso et al., 2004).

The state of a system depends on the history of disturbances, since an ecosystem is set to provide resilience to buffer changes for certain periods of time (Beisner et al., 2003; Zhang et al., 2003). The restoration of ecosystems into a natural stable state should be focused on monitoring events after the cessation of a perturbation and the responses to the reversal of a perturbation. Thus, integrated catchment management and the reduction of nutrient loads from all sources, together with additional measures (e.g. directional habitat reconstruction) are the way for long-term management solution for estuarine systems.

\section{Acknowledgments}

This study was supported by the POCTI - Formar e Qualificar - Medida 1.1 program (Portuguese FCT) through a Post-Doc grant (SFRH/BPD/5650/2001) (A. I. Lillebø), and a PhD grant (Praxis XXI/BD/18422/98) to J.M. Neto.

\section{References}

Asmus, R.M., Sprung, M., Asmus, H., 2000. Nutrient fluxes in intertidal communities of a south European lagoon (Ria Formosa) similarities and differences with a northern wadden sea bay (SylRømø bay). Hydrobiologia 436, 217-235.

Beisner, B.E., Haydon, D.T., Cuddington, K., 2003. Alternative stable stages in ecology. Frontiers in Ecology and the Environment 1, 376-382. www.frontiersinecoly.org.

Berner, E.K., Berner, R.A., 1996. Marginal marine environments: estuaries. In: The Global Environment: Water, Air and Geochemical Cycles. Prentice-Hall, Upper Saddle River, NJ, pp. 284-311.
Beukema, J.J., Flach, G.C., Dekker, R., Starink, M., 1999. A longterm study of the recovery of the macrozoobenthos on large defaunated plots on a tidal flat in the Wadden Sea. Journal of Sea Research 42, 235-254.

Cardoso, P., Pardal, M.A., Lillebø, A.I., Ferreira, S.M., Raffaelli, D., Marques, J.C., 2004. Dynamic changes in seagrass assemblages under eutrophication and implications for recovery. Journal of Experimental Marine Biology and Ecology 302, 233-248.

Coelho, J.P., Flindt, M.R., Jensen, H.S., Lillebø, A.I., Pardal, M.A., 2004. Phosphorus speciation and availability in intertidal sediments of a temperate estuary: relation to eutrophication and annual P-fluxes. Estuarine, Coastal and Shelf Science 61, 583-590.

Collos, Y., 1998. Nitrate uptake, nitrite release and uptake, and new production estimates. Marine Ecology Progress Series 171, 293-301.

Dolbeth, M., Pardal, M.A., Lillebø, A.I., Azeiteiro, U., Marques, J.C., 2003. Short term and long term effects of eutrophication on the secondary production of an intertidal macrobenthic community. Marine Biology 143, 1229-1238.

Hayden, H.S., Blomster, J., Maggs, C.A., Silva, P.C., Stanhope, M.J., Waalland, J.R., 2003. Linnaeus was right all along: Ulva and Enteromorpha are not distinct genera. European Journal of Phycology 38, 277-294.

Hein, M., Pedersen, M.F., Sand-Jensen, M., 1995. Size dependent nitrogen uptake in micro-and macroalgae. Marine Ecology Progress Series 118, 247-253.

Holmboe, N., Jensen, H.S., Andersen, F.Ø., 1999. Nutrient addition bioassays as indicators of nutrient limitation of phytoplankton in an eutrophic estuary. Marine Ecology Progress Series 186, 95-104.

Jensen, H.S., Andersen, F.Ø., 1992. Importance of temperature, nitrate and $\mathrm{pH}$ for phosphate release from aerobic sediments of four shallow, eutrophic lakes. Limnology and Oceanography 37, $577-589$.

de Jonge, V.N., 2000. Importance of temporal and spatial scales in applying biological and physical process knowledge in coastal management, an example for the Ems estuary. Continental Shelf Research 20, 1655-1686.

de Jonge, V.N., de Jong, D.J., 2002. Ecological restoration in coastal areas in the Netherlands: concepts, dilemmas and some examples. Hydrobiologia 478, 7-28.

van Katwijk, M.M., Hermus, D.C.R., de Jong, D.J., Asmus, R.M., de Jonge, V.N., 2000. Habitat suitability of the Wadden Sea for restoration of Zostera marina beds. Helgoland Marine Research 54, 117-128.

Kendrick, G.A., Aylward, M.J., Hegge, M.L., Cambridge, K., Hillman, K., Wyllie, A., Lord, D.A., 2002. Changes in seagrass coverage in Cockburn Sound, Western Australia between 1967 and 1999. Aquatic Botany 73, 75-87.

Lillebø, A.I., Flindt, M.R., Pardal, M.A., Martins, I., Neto, J.M., Marques, J.C., 2002. Nutrient dynamics in the intertidal pools of the Mondego estuary. II - Seasonal efflux of $\mathrm{PO}_{4}-\mathrm{P}$ and $\mathrm{NH}_{4}-\mathrm{N}$ in bare bottom and vegetated pools. In: Pardal, M.A., Marques, J.C., Graça, M.A. (Eds.), Aquatic Ecology of the Mondego River Basin. Global Importance of Local Experience. Imprensa da Universidade de Coimbra, Coimbra, pp. 257-272.

Lillebø, A.I., Neto, J.M., Flindt, M.R., Marques, J.C., Pardal, M.A., 2004. Phosphorous dynamics in a temperate intertidal estuary. Estuarine, Coastal and Shelf Science 61, 101-109.

Limnologisk Metodik, 1992. Ferskvandsbiologisk Laboratorium. Københavns Universitet (Ed.), Akademisk Forlag. København, 172 pp.

Marques, J.C., Nielsen, S.N., Pardal, M.A., Jørgensen, S.E., 2003. Impact of eutrophication and river management within a framework of ecosystem theories. Ecological Modelling 166, 147-168.

Martins, I., Pardal, M.A., Lillebø, A.I., Flindt, M.R., Marques, J.C., 2001. Hydrodynamics as a major factor controlling the occurrence of green macroalgal blooms in a eutrophic estuary: a case study on the influence of precipitation and river management. Estuarine, Coastal and Shelf Science 52, 165-177. 
McMahon, K., Walker, D.I., 1998. Fate of seasonal, terrestrial nutrient inputs to a shallow seagrass dominated embayment. Estuarine, Coastal and Shelf Science 46, 15-25.

Norkko, A., Bonsdorff, E., Norkko, A., 2000. Drifting algal mats as an alternative habitat for benthic invertebrates: species specific responses to a transient resource. Journal of Experimental Marine Biology and Ecology 248, 79-104.

Pardal, M.A., Cardoso, P.G., Sousa, J.P., Marques, J.C., Raffaelli, D., 2004. Assessing environmental quality: a novel approach. Marine Ecology Progress Series 267, 1-8.

Parsons, T.R., Maita, Y., Lally, C.M., 1985. Pigments. In: A Manual of Chemical and Biological Methods for Seawater Analysis. Pergamon Press, pp. 101-104.

Raffaelli, D.G., Raven, J.A., Poole, L.J., 1998. Ecological impact of green macroalgal blooms. Oceanography and Marine Biology. Annual Review 36, 97-125.

Rocha, C., Cabeçadas, G., Brogueira, M.J., 1995. On the importance of sediment-water exchange processes of ammonia to primary production in shallow areas of the Sado estuary (Portugal). Netherlands Journal of Aquatic Ecology 29, 265-273.

Scheffer, M., Carpenter, S., Foley, J.A., Folke, C., Walker, B., 2001. Catastrophic shifts in ecosystems. Nature 413, 591-596.

Sfriso, A., Birkmeyer, T., Ghetti, P.F., 2001. Benthic macrofauna changes in areas of Venice lagoon populated by seagrasses or seaweeds. Marine Environmental Research 52, 323-349.
Strickland, J.D.M., Parsons, T.R., 1972. A Practical Handbook of Seawater Analysis (Bulletin 167, second ed.). In: Fisheries Research Board of Canada, Ottawa, pp. 71-80.

Valiela, I., McClelland, J., Hauxwell, J., Behr, P.J., Hersh, D., Foreman, K., 1997. Macroalgal blooms in shallow estuaries: Controls and ecophysiological and ecosystem consequences. Limnology and Oceanography 4215, 1105-1118.

Webster, I.T., Harris, G.P., 2004. Anthropogenic impacts on the ecosystems of coastal lagoons: modelling fundamental biogeochemistry process and management implications. Marine and Freshwater Research 55, 67-78.

Widdows, J., Brinsley, M., 2002. Impact of biotic and abiotic processes on sediment dynamics and the consequences to the structure and functioning of the intertidal zone. Journal of Sea Research 48, 143-156.

Yin, K., Qiam, P., Wu, M.C.S., Chen, J.C., Huang, L., Song, X., Jian, W., 2001. Shift from $\mathrm{P}$ to $\mathrm{N}$ limitation of phytoplankton growth across the Pearl River estuarine plume during summer. Marine Ecology Progress Series 221, 17-28.

Zhang, J., Jørgensen, S.E., Beklioglu, M., Ince, O., 2003. Hysteresis in vegetation shift - Lake Mogan prognoses. Ecological Modelling 164, 227-238.

Zwolsman, J.J.G., 1994. Seasonal variability and biogeochemistry of phosphorus in the Scheldt Estuary, South-west Netherlands. Estuarine, Coastal and Shelf Science 39, 227-248. 